\title{
KONTRAK PEGADAIAN BARANG DAN JASA \\ DI DINAS PEKERJAAN UMUM KABUPATEN BREBES \\ DITINJAU DARI PRESPEKTIF KENOTARIATAN
}

\author{
Rizqi Iman Aulia Luqmanul Hakim*, Maryanto* \\ * Mahasiswa Program Magister (S2) Kenotariatan Fakultas Hukum UNISSULA, Semarang, e-mail: \\ rizqi_kibbo@yahoo.com \\ ** Dosen Fakultas Hukum UNISSULA, Semarang
}

\begin{abstract}
The Goods and Services Procurement Agreement is a complex agreement because it regulates many aspects both legally and technically about the procurement process of goods and services, requiring further study in order to find the ideal contract format for procurement of goods and services in accordance with the needs and able to provide protection and certainty law for the parties that make it.

The problems in this research are: 1) How is the legal force of the government procurement contract made under the hands? 2) How is Notary's role in making government procurement contracts? 3) How is the legal protection of the parties in the event of breach of contract (wanprestasi) that harms the State?

Approach method used in this research is normative juridical approach method, this research specification is analytical descriptive, data source that is primary and secondary data, data collecting method use by library study, method of data analysis with qualitative analysis.

Result of research: 1) Agreement under the hand signed by the parties concerned. Such an agreement is only binding on the parties to the treaty but has no binding power to a third party. 2) Notary's role in the manufacture of Government Procurement of Goods and Services Contract in the form of an authentic deed, According to Article 1 paragraph 1 of Law Number 2 Year 2014 Notary Public Notary: Public Notary is authorized to make authentic deeds and other powers as referred to in the Act, 3) The protection of the law shall be initiated by the obligation of the parties to enter into a procurement agreement of goods and services by containing the clauses already stipulated as one of the legal protection measures for the parties, in the charter agreement.

Suggestions in this research is Need a good coordination between the assignor, contractor, planner and supervisor in the implementation pemborongan building. With good coordination, the implementation of building projects can be implemented efficiently, effectively and planned.
\end{abstract}

Keywords: Contract, Goods And Services From, Notary's Perspective

\section{PENDAHULUAN}

\section{Latar Belakang Masalah}

Pegadaan barang dan jasa biasanya melibatkan adanya perjanjian. Perjanjian yang dibuat dari pengadaan barang dan jasa biasanya bersifat kompleks. Hal ini disebabkan karena adanya sisi legalitas dan sisi teknis dari pengadaan barang dan jasa itu sendiri. Kompleksitas pengadaan barang dan jasa menuntut adanya format atau sistem dari kontrak perjanjian tersebut yang ideal dan berkekuatan hukum. Praktek perjanjian pengadaan komoditas barang dan Jasa di Indonesia adalah perjanjian standar. Perjanjian kontrak atau kontrak standar merupakan perjanjian yang telah disiapkan oleh salah satu pihak sebelum terjadinya transaksi dan pihak lainnya tidak mempunyai wewenang menyusun dan membuat isi dari kontrak dan hanya bisa menentukan pilihan antara menerima ataupun menolak kontrak.

Pembuatan kontrak standar dapat berupa tulisan ataupun lisan. Dalam kegiatan pemborongan dari pengadaan barang dan jasa dalam jumlah budget yang besar, para pihak membuat perjanjian yang sifatnya tertulis. Secara aplikatif, perjanjian tertulis terbagi menjadi 3 (tiga) yaitu pertama, perjanjian di bawah tangan, dimana pihak yang bertandatangan adalah pihak-pihak yang berkepentingan saja. Kedua, perjanjian dengan melibatkan 
Notaris sebagai pihak yang bersaksi dari perbuatan hukum yang diadakan oleh para pihak yang berkepentingan. Adanya kesaksian dari Notaris dari sebuah dokumen sangat berguna untuk mengesahkan tanda tangan dari para pihak. Ketiga, perjanjian dalam bentuk akta notariil dimana perjanjian tersebut dibuat di hadapan dan oleh Notaris.

Perjanjian pengadaan komoditi barang dan jasa dapat dilaksanakan dengan cara pelelangan, penunjukkan secara langsung, ataupun swakelola. Pengadaan komoditi barang dan jasa merupakan sistem yang bebas dari tekanan. Ketentuan ini sesuai dengan Perpres No.54 Tahun 2010 tentang Pengadaan Barang/Jasa Pemerintah. Penelitian ini hendak menjawab pertanyaan : Bagaimana kekuatan hukum kontrak pengadaan barang dan jasa pemerintah yang dibuat di bawah tangan?; Bagaimana peran Notaris terhadap pembuatan kontrak pengadaan barang dan jasa pemerintah?; Bagaimana perlindungan hukum terhadap para pihak pada saat terjadi pelanggaran kontrak (wanprestasi) yang merugikan Negara? Metode pendekatan yang digunakan dalam penelitian ini adalah metode pendekatan yuridis normatif. Spesifikasi penelitian ini bersifat deskriptif analitis. Sumber data yaitu data primer dan sekunder, metode pengumpulan data menggunakan cara studi pustaka, metode analisa data dengan analisa kualitatif.

\section{A. PEMBahasan}

\section{Kekuatan Hukum Kontrak Pengadaan Barang Dan Jasa Pemerintah Yang Dibuat Di Bawah Tangan}

Pengadaan barang dan jasa dari pihak kontraktor dengan Pemerintah dalam rangka menyediakan komoditi barang dan jasa untuk menunjang kinerja dan pelaksanaan sistem pemerintahan yang baik ini tertuang dalam sebuah perjanjian. Perjanjian ini dimaksudkan adalah perjanjian pemborongan, dimana memunculkan hubungan hukum antara pemberi borongan dalam hal ini Pemerintah Kabupaten Brebes yang diwakili oleh Dinas Pekerjaan Umum dan pihak C.V. Aria Duta sebagai pihak kontraktor. Hubungan ini berakibat pihak pemberi jasa borongan untuk menggunakan jasa pemborongan dengan adanya imbalan berupa biaya bagi kontraktor sebagai bentuk pembayaran atas jasa yang telah diberikan
Perjanjian yang diadakan oleh C.V. Aria Duta dipraktekkan dalam bentuk tertulis dan bersifat di bawah tangan. Dimana susunan perjanjian pengadaan komoditi barang dan jasa dilakukan dan ditentukan secara sepihak dan pihak pengguna jasa pemborongan hanya menyetujui atau menolaknya. Secara prosedural, perjanjian yang dibuat mengacu pada kententuan perjanjian standar.

Keadaan ini dimaksudkan agar tidak terjadi diskriminasi dalam pembuatan perjanjian pemborongan antara C.V. Aria Duta dengan klien (konsumen). Perjanjian yang dibuat memuat syarat dan ketentuan yang sama untuk semua klien. Ketentuan tersebut adalah surat perjanjian berangkapkan 2 lembar yang semuanya bermaterai dan dibubuhkan tanda tangan pihak-pihak yang terkait.

Pemborong/kontraktor dalam perjanjian pengadaan barang dan jasa bertanggungjawab ketika ada sub-kontraktor. Penulis beranggapan bahwa secara yuridis, hubungan hukum subkontraktor hanya dengan kontraktor utamanya saja, yang dituangkan dalam perjanjian.

Terdapat satu hal yang harus diketahui oleh kontraktor yaitu tidak dibenarkannya kontraktor melakukan sub-kontraktor dari pekerjaan yang diborong, baik semua ataupun sebagian. Apabila hal ini terjadi maka perjanjian tersebut dapat dibatalkan. Sementara itu kerugian yang timbul akibat perbuatan kontraktor maka kontraktor bisa saja terkena sanksi dalam bentuk denda yang besaranya diukur sesuai dengan ketentuan yang dimuat dalam perjanjian.

\section{Peran Notaris Terhadap Pembuatan Kontrak Pengadaan Barang Dan Jasa Pemerintah}

Notaris mempunyai ruang lingkup kinerjanya dimana Notaris jangan sampai ikut campur ketika terjadi penentuan hak antara masing-masing pihak. Akan tetapi jikalau terkait pembuatan suatu bentuk hukum/perjanjian maka Notaris mempunyai peranan sangat penting dan pihak dari nasihat hukum (Lawyer) hanya mempunyai peran sebagai penasehat saja. ${ }^{1}$

Notaris dalam menjalankan tugasnya sebagai pejabat umum telah mendapatkan pengakuan

1 R. Subekti, Hukum Pembuktian, Cet. Ke-8, (Jakarta: Pramadya Paramita, 1987), hlm. 27. 
eksistensinya secara langsung dari kekuasaan eksekutif $^{2}$ dimana tugas terkait bidang hukum perdata yang dikerjakan masyarakat telah diakui oleh Negara.

Subekti juga memberikan penjelasan bahwa kontak yaitu perjanjian yang tertulis. Disamping itu konsep dari perjanjian adalah suatu keadaan dimana seseorang mengikatkan diri dengan orang/pihak lain dalam rangka menjalankan suatu perbuatan. KUHPer juga mendefinisikan bahwa perikatan adalah usaha untuk memberi sesuatu, untuk berbuat sesuatu, atau tidak untuk berbuat sesuatu.

Dengan melihat perjanjian pengadaan komoditi barang dan jasa pemerintah sebagai bentuk perjanjian yang sifatnya terbuka, transparan dan masyarakat juga perlu mengetahui pihak dari yang mengadakan, maka perjanjian tersebut perlu dilaksanakan di hadapan atau oleh pejabat berwenang yang dalam hal ini adalah Notaris. Ini dimaksudkan agar perjanjian yang dibuat tersebut dapat menjadi undang-undang bagi pihak-pihak yang mengadakan dan menjadi bukti yang otentik ketika dipergunakan di ranah pengadilan.

\section{Perlindungan Hukum Terhadap Para Pihak Pada Saat Terjadi Pelanggaran Kontrak (Wanprestasi) Yang Merugikan Negara}

Ketentuan mengenai kontrak disebutkan di Keppres Nomor 80 Tahum 2003 yaitu keadaan terikatnya perikatan antara Pengguna barang/jasa dengan Penyedia barang/jasa dalam pelaksanaan pengadaan barang/jasa.

Pengertian tersebut terdapat dua pihak yang mengikatkan diri yaitu pengguna jasa dan penyedia jasa. Pengguna jasa diwakili oleh PPK dan dari penyedia jasa diwakili oleh pejabat atau orang untuk menandatangani proyek tersebut.

Perjanjian pengadaan barang dan jasa Pemerintah yang dibuat dan ditandatangani di hadapan Notaris selaku pejabat yang berwenang membuat akta otentik menjadikan perjanjian yang dibuat itu bersifat sempurna dan memberikan keabsahan dari identitas ataupun wewenang dari penandatangan perjanjian tersebut.

2 GHS Lumban Tobing, Peraturan Jabatan Notaris, (Jakarta: Erlangga, 1983), hlm.37

\section{PENUTUP}

\section{Kesimpulan}

a. Hukum perjanjian pengadaan komoditi barang dan jasa Pemerintah yang dibuat di bawah tangan

Penerapan perjanjian pengadaan komoditi barang dan jasa oleh pihak Pemerintah Kabupaten Brebes yang hal ini dilakukan oleh Dinas Pekerjaan Umum dengan pemborong yang dalam hal ini pihak C.V. Aria Duta dilaksanakan berdasarkan kesepakatan di bawah tangan. Format pembentukan perjanjian tersebut telah dirancang dan dibuat oleh pihak pemborong yang sesuai dengan perjanjian standar dan pihak Dinas hanya menyetujui dan menandatangani perjanjian tersebut. Pembuatan perjanjian di bawah tangan tersebut didasari unsur efisiensi waktu dan biaya. Perjanjian yang seperti ini hanya akan menjadi undang-undang bagi pihak yang menyelenggarakan kesepakatan, tidak bisa mengikat pada pihak ketiga. Sehingga apabila terjadi tuntutan dari pihak ketiga maka pihakpihak yang mengadakan kesepakatan tersebut atau salah satunya harus mempunyai buktibukti terkait keabsahan perjanjian yang dibuat sehingga pihak ketiga memang tidak dibenarkan tuntutannya.

b. Kontribusi Notaris dalam pembuatan Perjanjian pengadaan barang dan jasa oleh pemerintah

Eksistensi Notaris sebagai pejabat publik di Indonesia yang mempunyai wewenang membuat akta otentik telah dilindungi dan dilegalkan dengan adanya Undang-Undang Jabatan Notaris. Kaitannya perjanjian pengadaan komoditi barang dan jasa pemerintah dengan pemborong, perlu melibatkan peran Notaris dalam pembuatan perjanjian tersebut. Akta otentik sebagai produk dari peran notaris akan memberikan perlindungan hukum bagi para pihak yang mengadakan perjanjian dan memperoleh alat bukti yang berkekuatan hukum kuat ketika terjadi suatu permasalahan atau sengketa dari pihak ketiga

c. Perlindungan hukum para pihak ketika terjadi wanprestasi.

Pembuatan perjanjian pengadaan komoditi barang dan jasa pemerintah yang dilaku- 
kan di hadapan Notaris akan menciptakan prinsip dan asas terbuka menjadi nyata terjadi, transparan, dan terlindunginya para pihak yang mengikatkan diri dalam suatu perjanjian. Hal ini menjadikan adanya kekuatan pembuktian yang sempurna dari akta notaris. Akta ini yang akan mengabsahkan dan membenarkan kedudukan dari perbuatan hukum yang terjadi yaitu perjanjian pengadaan komoditi barang dan jasa serta kedudukan dari para pihak yang menorehkan tanda tangan di atas akta tersebut. Sehingga perlindungan objektif dan otentik akan melindungi para pihak dari pihak ketiga ataupun pihak pengawas. Dan apabila terjadi sesuatu yang dapat merugikan negara (wanprestasi) maka perjanjian pengadaan barang komoditi barang dan jasa yang dibuat di hadapan Notaris akan menjadi bukti otentik dan sempurna.

\section{Saran}

1. Pelaksanaan perjanjian pengadaan komoditi barang dan jasa pemerintah harus melibatkan unsur koordinasi yang baik dimana informasi dan pemahaman akan hak dan kewajiban dapat dimengerti oleh masing-masing pihak antara Dinas Pekerjaan Umum, kontraktor, pengawas dan perencana pembangunan dalam pengadaan barang dan jasa.

2. Ketegasan dari pihak PPK (Dinas Pekerjaan Umum) ketika pihak kontraktor mulai kendor dalam pelaksanaan kewajibannya yaitu pengadaan komoditi barang dan jasa, sehingga kerugian (wanprestasi) dapat dicegah dan Negara tidak menanggung kerugian.

3. Insentifitas pengawasan sejak awal sampai selesainya kontrak dari pihak pengawas terhadap bangunan/barang/jasa yang sedang dilakukan pengadaan oleh pihak kontraktor, sehingga output dari perjanjian pengadaan barang dan jasa tidak merugikan.

\section{DAFTAR PUSTAKA}

A. Qiram Syamsudin Meliala, Pokok-Pokok Hukum Perjanjian Beserta Perkembangannya, Yogyakarta: Liberty, 1985
Abdul Kadir Muhammad, 2000, Hukum Perdata Indonesia, PT. Citra Aditya Bakti, Bandung.

Ahmad Syu'aib Abu Abd ar-Rahman Nasa'i, Sunan an-Nasa'i (al-Mujtaba). VII,

Ahmadi Miru, 2007, Hukum Kontrak Perencanaan Kontrak, PT. RajaGrafindo Persada, Jakarta

Badan Pendidikan dan Pelatihan Keuangan, Pelaksanaan Pengadaan Barang dan Jasa Pemerintah. Bahan Ajar DTSS Pengadaan Barang dan Jasa (Jakarta, 2007)

Bambang Hartoyo, Kajian Yuridis Pelaksanaan Fungsi Kenotariatan Pada Perwakilan Republik Indonesia Diluar Negeri, (Tesis Magister Kenotariatan Universitas Indonesia, Depok, 2007

R. Subekti dan Tjitrosoedibio, Kamus Hukum, cet. 13, (Jakarta: Pradnya Paramita, 2000).

R. Subekti, Aneka Peerjanjian, PT.Citra Aditya Bakti, Cetakan Kesepuluh,Bandung, 1995

R.Subekti, Hukum Pembuktian, cet. Ke-8, (Jakara: Pramadya Paramita, 1987)

Salim, 2003, Perkembangan Hukum Kontrak Innominaat di Indonesia, Sinar Garfika, Jakarta

Salim, Hukum Kontrak Teori dan Penyusunan Kontrak, Jakarta: PT, Grafindo Persada, 2009.

Soerjono Soekanto dan Sri Mamudji, Penelitian Hukum Normatif Suatu Tinjauan Singkat, Raja Grafindo, Jakarta, 2001

\section{A. Peraturan Perundang-Undangan}

Undang-Undang Nomor 2 tahun 2014 tentang Jabatan Notaris

Peraturan Presiden Republik Indonesia Nomor 4 Tahun 2015 tentang Perubahan Keempat atas Peraturan Presiden Nomor 54 Tahun 2010 tentang Pengadaan Barang/Jasa Pemerintah

Peraturan Kepala Lembaga Kebijakan Pengadaan Barang/Jasa Pemerintah Nomor 14 Tahun 2012 tentang Petunjuk Teknis Peraturan Presiden Nomor 70 Tahun 2012 Perubahan Kedua Peraturan Presiden Republik Indonesia Nomor 54 Tahun 2010 tentang Pengadaan Barang dan Jasa Pemerintah 